\section{Dominasi Maskulin dalam Akronim Pornografis}

\author{
Aditya Wicaksono \\ Sailal Arimi* \\ Linguistics Master Program, \\ Universitas Gadjah Mada \\ *sailal_arimi@ugm.ac.id
}

\begin{abstract}
ABSTRAK
Penelitian ini bertujuan untuk mendeskripsikan bentuk, makna, dan dominasi maskulin dalam akronim pornografis. Penelitian ini menggunakan pendekatan sosiolinguistik, khususnya kajian bahasa dan gender. Data penelitian diperoleh di dalam media sosial twitter. Hasil penelitian ini adalah (1) bentuk akronim pornografis di twitter antara lain berupa, akronim tiga kata, akronim suku kata awal dengan suku kata awal, akronim suku kata awal dengan suku kata akhir, dan akronim dengan kata metatesis, campur kode ke dalam (bahasa Indonesia dengan bahasa daerah), campur kode ke luar (bahasa Indonesia dengan bahasa Inggris), bahasa prokem, dan bahasa Inggris. (2) Makna akronim pornografis mengalami perluasan dari makna-makna leksikal yang menjadi unsur pembentuk akronim. Hal tersebut disebabkan oleh faktor-faktor di luar bahasa yang menjadi konteks pornografi, seperti foto dan video. (3) Dominasi maskulin dalam akronim pornografi dapat dilihat dari gender maskulin menciptakan dan mengembangkan pembentukan akronim pornografis, yang dapat dilihat berdasarkan frekuensi laki-laki membicarakan topik pornografi lebih besar dibandingkan perempuan. Lalu, terdapat pula kekerasan simbolik terhadap gender feminin karena berdasarkan referen akronim pornografi, feminin memiliki presentase lebih besar dibandingkan dengan maskulin, sehingga feminin dijadikan sebagai objektivikasi dalam pembentukan akronim pornografis.
\end{abstract}

Kata kunci: akronim; pornografi; dominasi; maskulinitas; gender

\title{
PENDAHULUAN
}

Di zaman modern ini, perilaku seksual tidak hanya dapat dilakukan secara langsung, namun dapat menggunakan cara-cara lain tanpa harus bertemu. Mulai dari chatsex, videosex, video-call sex dan phonesex dapat alternatifnya. Selain itu, pemuasan hasrat seksual juga dapat ditemukan dalam beberapa wacana berupa cerita pendek dewasa yang mudah ditemukan di internet. Hal ini pun dilatarbelakangi oleh teknologi yang berkembang pesat. Setiap orang dimudahkan dalam mengakses wacana porno hanya dengan menggunakan laptop atau telepon genggam. Koneksi internet yang semakin mudah dijangkau, sangat membantu untuk pemuasan hasrat seksual, baik secara virtual atau bertransaksi dengan pekerja seks komersial. Transaksi pun bisa dilakukan dengan mudah dengan adanya media sosial penunjang, seperti instagram, twitter, dan aplikasi kencan daring.

Berdasarkan fenomena tersebut, digunakanlah istilah yang menjadi kode dari sebuah komunitas penikmat seksual untuk meluapkan hasrat birahi. Media yang menghubungkan tersebut salah satunya menggunakan bahasa. Budaya seksual yang ada di dalam penggunaan istilah pornografis ini merupakan salah satu bentuk budaya karena menggunakan bahasa yang sifatnya abstrak, terdapat sistem sosial, dan dapat didokumentasikan (Koentjaraningrat 2009).

Porno berasal dari kata porn dalam bahasa Inggris yang berarti penggambaran melalui gambar dan tulisan yang bersifat erotis dan menimbulkan nafsu birahi. Pornografis ialah sifat-sifat yang berkenaan dengan sesuatu yang porno atau seksual. Menurut (Sugihastuti dan Sastriyani 2007) pornografi merupakan penggambaran tingkah laku secara erotis dengan tulisan atau lukisan untuk membangkitkan nafsu birahi, bahan bacaan yang dengan sengaja dan semata-mata dirancang untuk membangkitkan nafsu birahi dalam seks, jenis kekerasan lain terhadap perempuan termasuk kekerasan nonfisik berupa eksploitasi tubuh perempuan sebagai objek untuk kepuasan seseorang. Di dalam penelitian ini, istilah pornografis didapatkan melalui wacana pornografi. 
Istilah pornografis sudah berkembang di dalam dunia noninternet. Bentuk penggunaan istilah pornografis dalam komunikasi sehari-hari antara lain sebagai ujaran catcalling, humor, dan percakapan akan atau ketika berhubungan seks. Dengan berkembangnya teknologi, semua kegiatan seseorang dapat beralih ke dunia virtual. Oleh sebab itu, kegiatan seksual dapat ditemukan di internet, salah satunya melalui media sosial. Media sosial adalah sebuah sarana untuk bersosialisasi satu sama lain dan dilakukan secara daring yang memungkinkan manusia untuk saling berinteraksi tanpa dibatasi ruang dan waktu. Contoh-contoh laman media sosial antara lain ; facebook, twitter, blog, youtube, dan wordpress. Twitter merupakan sebuah ruang atau platform yang dapat disebut sebagai jejaring sosial. Salah satu bentuk dari istilah pornografis adalah akronim pornografis.

Media sosial yang akan dibahas pada penelitian ini adalah twitter. Twitter adalah sebuah media sosial yang digunakan untuk bercuit (mengutarakan ekspresi menggunakan bahasa), mengunggah gambar, dan video. Twitter juga dapat memanifestasikan eskpresi pornografis, baik dalam bentuk bahasa, gambar, atau video. Di dalam twitter, juga terdapat fitur utas yang memungkinkan pihak lain dapat mengomentari cuitan seseorang. Akronim pornografis merupakan salah satu akses untuk mengetahui wacana pornografis di twitter.

Secara umum, penelitian ini menggunakan pendekatan gender dan bahasa dalam analisis akronim pornografis. Terdapat tiga fokus analisis di dalam penelitian ini; deksripsi bentuk akronimi, deskripsi pemaknaan akronim pornografis, dan dominasi maskulinitas dalam akronim pornografis. Penelitian ini merupakan salah satu kajian sosiolinguistik.

Sosiolinguistik merupakan ilmu yang mengamati cara seseorang menggunakan bahasa dalam perbedaan konteks sosial dengan mendeskripsikan kekayaan informasi mengenai cara bahasa bekerja yang berkaitan dengan hubungan sosial di dalam sebuah komunitas tutur dan cara seseorang dalam menyampaikan serta mengonstruksi aspek identitas sosial mereka dalam bahasa yang digunakan (Holmes 2012). Bahasa memiliki relasi dengan kelas sosial, status, letak geografis, gender, dan usia (Mesthrie 2009). Aspek indeksial tersebut dapat terepresentasikan dalam ciri berbahasa individu (kecuali aksen), yang dapat mengindikasikan komunitas sosial atau latar belakang individu. Kaitan gender dengan pemakaian bahasa merupakan kajian sosiolinguistik karena gender merupakan salah satu fakta sosial yang mempengaruhi bahasa.

Bahasa yang digunakan oleh pria dan wanita memiliki perbedaan. Bentuk perbedaan bahasa oleh gender dapat dilihat melalui eksklusivitas gender dan preferensial gender. Preferensial gender adalah perbedaan preferensi penggunaan bahasa oleh gender yang bersifat bertingkat dan tidak mutlak (Talbot 2003).

Tuturan pria dan wanita pada dasarnya menggunakan bentuk linguistik yang tidak sepenuhnya berbeda (Holmes 2012). Pria dan wanita menggunakan kuantitas dan frekuensi yang berbeda dalam suatu bentuk yang sama. Meskipun pria dan wanita menggunakan beberapa bentuk yang berbeda, salah satu gender memiliki salah satu preferensi atau kecenderungan lebih banyak dibandingkan gender lain dalam memilih bahasa yang digunakan. Akronim pornografis merupakan salah satu tuturan kasar atau tabu. Terdapat asumsi yang menyatakan bahwa kata kasar merupakan jenis kata milik laki-laki dan terlarang untuk perempuan dan anak-anak (Fine dan Johnson 1984). Di dalam penggunaan akronim pornografi, terdapat dominasi maskulinitas yang dapat dilihat dari penciptaan dan perkembangan akronim pornografis serta terdapat kekerasan simbolik terhadap salah satu gender yang terdominasi.

Pierre Bourdieu mengungkapkan dalam dominasi maskulin terdapat kekerasan simbolik. Kekerasan itu pada dasarnya melibatkan komunikasi dan pengetahuan. Komunikasi dan pengetahuan itu murni bersifat simbolik atau lebih tepatnya harus dikatakan bahwa kekerasan itu dilakukan dengan caracara penghinaan, pengakuan atau pada batas tertentu, dengan cara-cara perasaan yang bersifat simbolik (Bourdieu 2010).

Data primer dalam penelitian ini adalah 20 akronim pornografis yang memiliki referen-gender (tidak bersifat bias gender) di media sosial twitter. Lalu, data sekunder penelitian ini adalah hasil dari survei berupa kuesioner tentang pemahaman akronim pornografi yang disebar secara daring. Hasil survei memperoleh 126 responden, sebanyak 60 responden laki-laki dan 68 responden perempuan. Metode penelitian dibagi dalam tiga tahap, yakni tahap pengambilan data, tahap analisis data, dan tahap penyajian hasil analisis data. Dalam pengambilan data, metode yang digunakan ialah metode simak 
dan survei. Teknik dasar dari metode simak yang digunakan ialah teknik sadap. Teknik sadap ialah peneliti dalam upaya mendapatkan data dilakukan dengan menyadap penggunaan bahasa seseorang atau beberapa orang yang menjadi informan (Mahsun 2012). Teknik lanjutan dari teknik sadap yang digunakan dalam penelitian ini ialah teknik simak bebas libat cakap, dengan teknik lanjutannya menggunakan teknik catat. Teknik bebas libat cakap maksudnya si peneliti hanya berperan sebagai pengamat penggunaan bahasa oleh para informannya (Mahsun 2012). Teknik catat digunakan untuk mencatat akronim pornografi yang ditemukan di media sosial twitter. Metode survei digunakan untuk memperkuat analisis data primer. Di dalam survei, terdapat 20 daftar pertanyaan mengenai pengetahuan akronim pornografis yang disebar melalui formulir google secara daring untuk mengetahui perbedaan antara laki-laki dan perempuan dalam mengetahui dan memahami akronim pornografis. Hasil survei memuat 128 responden (6o laki-laki dan 68 perempuan) yang secara otomatis data disajikan melalui bagan presentase. Dalam menganalisis, cara yang digunakan adalah menguraikan akronim menjadi bentuk yang lebih kecil lagi, menganalisis penggunaannya di dalam media sosial twitter, dan menganalisis perubahan makna dari bentuk asli dan bentuk yang sudah menjadi akronim, dan menganalisis perbedaan pengetahuan laki-laki dan perempuan tentang akronim pornografis. Metode yang digunakan dalam menyajikan hasil analisis ialah metode informal, yakni bersifat deskriptif dengan menguraikan fakta yang ada dan metode formal, yakni menampilkan diagram berupa presentase.

\section{PEMBAHASAN}

\section{Bentuk Lingual Akronim Pornografis}

Secara bentuk lingual, istilah pornografis dapat diidentifikasikan berdasarkan proses pembentukan akronim. Proses pembentukan akronim dapat dilihat melalui pola akronimi dan pemakaian ragam bahasa yang digunakan dalam akronimi. Akronimi adalah proses pemendekan yang menggabungkan huruf atau suku kata atau bagian lain yang ditulis dan dilafalkan sebagai sebuah kata yang sedikit banyak memenuhi kaidah fonotaktik suatu bahasa, sedangkan akronim adalah kependekan yang berupa gabungan huruf atau suku kata atau bagian lain yang ditulis dan dilafalkan sebagai kata yang sesuai dengan kaidah fonotaktik bahasa bersangkutan (Kridalaksana 2001). Akronim dapat diklasifikasikan berdasarkan bentuknya menjadi tiga macam, yaitu akronim dari huruf awal kata, akronim dari suku kata atau penggalan kata, dan akronim dari huruf awal kata dengan suku kata atau penggalan kata (Tarigan 1988). Berikut ini adalah beberapa varian akronim berdasarkan bentuk atau pola akronimi
(1) toge
(2) tocil
(3) meki
(4) sagapung
(5) igo
(6) ngewe

Data (1) merupakan akronim dari toket gede. Pola akronimi dalam data (1) berupa penggabungan suku kata awal masing-masing unsur, yakni silabe/to/ dari toket dengan silabe/ge/ dari gede. Data (2) merupakan akronim dari toket kecil. Pola akronimi dalam data (2) berupa penggabungan suku kata awal unsur pertama dengan suku kata akhir unsur kedua, yakni silabe/to/ dari toket dengan silabe /cil/ dari kecil. Data (3) merupakan akronim dari memek kecil. Pola akronimi dalam data (3) berupa penggabungan suku kata awal unsur pertama dengan penggalan bunyi pada unsur kedua, yakni silabe /me/ dari memek dengan penggalan bunyi /ki/ dari kecil.

Data (4) merupakan akronim dari sange gak ketampung. Akronimi dalam data (4) berasal dari suatu kalimat ragam nonformal. Pola akronimi dalam data (4) berupa penggabungan suku kata awal unsur pertama, suku kata awal dengan modifikasi bunyi pada unsur kedua, dan suku kata akhir dalam unsur ketiga. Akronimi data (4) berupa silabe /sa/dari sange, silabe /ga/dari gak, dan silabe /pung/dari ketampung. Data (5) merupakan akronim dari Indonesian girl only. Pola akronimi dalam data (5) berupa pengambilan huruf awal kata di masing-masing unsur, yakni huruf/i/ dari Indonesian, huruf /g/ dari girl, dan huruf /o/ dari only. Data (6) merupakan akronim dari ngentot cewe. Ngentot merupakan akronim dari ngencan total. Jadi, data (6) merupakan akronimi dari sebuah kata dengan sebuah akronim. Pola akronim dalam data (6) berupa suku kata awal unsur pertama dengan suku kata awal 
Aditya Wicaksono \& Sailal Arimi

dengan modifikasi bunyi pada unsur kedua, yakni silabe /nge/ dari ngentot dengan penggalan kata /we/ dari cewe.

Selain berdasarkan pola akronimi, bentuk lingual akronim pornografis dapat ditilik berdasarkan pemakaian ragam bahasa. Dalam penelitian ini ditemukan beberapa varian pemakaian bahasa pada akronim pornografis antara lain penggunaan campur kode, bahasa daerah, bahasa Inggris, bahasa prokem, dan metatesis.
(1) toge
(5) igo
(7) kimcil
(8) coli
(9) jilboobs

Data (1) merupakan akronim dari toket gede. Toket merupakan kata dalam ragam bahasa prokem. Menurut Ensiklopedi Nasional Indonesia (1990: 406-7), bahasa prokem adalah suatu bentuk bahasa yang digunakan oleh kelompok remaja tertentu yang tergabung dalam kelompok atau geng di Jakarta. Toket berasal dari kata tete (payudara), yang mengalami modifikasi dengan penyisipan huruf lok/ dan pengilangan huruf /e/ di akhir kata. Data (5) merupakan akronim dari Indonesian girl only. Indonesian girl only merupakan frasa dalam bahasa Inggris yang berarti "hanya perempuan Indonesia." Data (7) merupakan akronim dari kimpet cilik. Kimpet merupakan metatesis dari kata dalam bahasa Jawa, tempik. Metatesis adalah perubahan letak huruf, bunyi, atau suku kata dalam kata; misal perubahan letak [r] dan [l] dalam rontal menjadi lontar (Kridalaksana 2001: 136). Lalu, unsur pembentuk akronim (7) ialah kata dalam bahasa Jawa, yakni tempik yang berarti "alat kelamin perempuan" dan cilik yang berarti "kecil".

Data (8) dan (9) merupakan akronim berupa campur kode. Campur kode ialah jenis pilhan bahasa yang menyisipkan kode-kode lain dalam memakai kode tertentu. Ciri lain dari gejala campur kode ialah bahwa unsur-unsur bahasa atau variasi-variasinya yang menyisip di dalam bahasa lain tidak lagi mempunyai fungsi tersendiri (Suwito 1985). Campur kode dapat dibedakan menjadi dua jenis, yakni campur kode ke luar dan campur kode ke dalam. Campur kode ke luar unsur-unsur yang diselipkan bersumber dari bahasa asing, sedangkan unsur-unsur yang diselipkan dalam campur kode ke dalam bersumber dari dialek-dialek bahasa daerah (Suwito 1985). Data (8) merupakan akronim dari kocok peli. Kocok merupakan kata dalam bahasa Indonesia, yang berarti kegiatan yang mengguncangkan sesuatu, sedangkan peli merupakan kata dalam bahasa Jawa yang berarti alat kemaluan laki-laki. Data (8) merupakan jenis akronimi campur kode ke dalam. Data (9) merupakan akronim dari jilbab boobs. Jilbab menurut KBBI V berarti kain longgar yang menutupi seluruh, termasuk kepala, rambut, dan telinga, kecuali tangan, kaki, dan wajah. Boobs merupakan kata dalam bahasa Inggris yang berarti payudara. Data (8) merupakan jenis campur kode ke luar.

\section{Pemaknaan Akronim Pornografis}

Proses pemaknaan di dalam akronim pornografis dilihat berdasarkan leksem pembentuk akronim. Akan tetapi, terdapat pula pemaknaan yang memperhatikan konteks wacana di dalam penggunaan akronim pornografis. Misal, pada akronim jilboobs, terdiri dari leksem "jilbab" dan "boobs" yang jika diartikan secara leksikal adalah "jilbab payudrara". Namun, jika dikaitkan dengan konteks wacana, akronim jilboobs bermakna "perempuan berjilbab yang memiliki payudara besar". Konteks wacana dapat dilihat melalui fitur-fitur di luar bahasa, misalnya foto. Berikut ini ialah tabel pembentukan akronim dan pemaknaan akronim pornografis

Tabel 1. Proses Akronimi dan Pemaknaan Akronim Pornografis

\begin{tabular}{llll}
\hline No. & AKRONIM & PROSES AKRONIMI & MAKNA \\
\hline 1 & coli & kocok + peli & Kegiatan mastrubasi bagi laki-laki \\
2 & palkon & kepala + kontol & Anatomi alat kelamin laki-laki \\
3 & koncil & kontol + kecil & Ukuran alat kelamin laki-laki yang kecil \\
4 & colbar & coli + bareng & $\begin{array}{l}\text { Kegiatan melakukan mastrubasi bersama untuk laki- } \\
\text { laki }\end{array}$ \\
\hline
\end{tabular}


Dominasi Maskulin dalam Akronim Pornografis

\begin{tabular}{|c|c|c|c|}
\hline 5 & bacol & bahan + coli & $\begin{array}{l}\text { Objek seksual yang dapat dijadikan sesuatu yang } \\
\text { memicu tindakan mastrubasi laki-laki }\end{array}$ \\
\hline 6 & colmek & colek + memek & $\begin{array}{l}\text { Kegiatan mastrubasi atau aktivitas seksual yang } \\
\text { berupa menggesek alat kelamin perempuan }\end{array}$ \\
\hline 7 & toge & toket + gede & Ukuran payudara perempuan yang besar \\
\hline 8 & ngewe & ngentot + cewe & Aktivitas seksual berupa penetrasi \\
\hline 9 & jilboobs & jilbab + boobs & $\begin{array}{l}\text { Perempuan berjilbab yang memiliki ukuran payudara } \\
\text { besar }\end{array}$ \\
\hline 10 & bispak & bisa + pakai & Perempuan yang dapat diajak berhubungan seksual \\
\hline 11 & bisyar & bisa + bayar & Perempuan berupa pekerja seks komersial \\
\hline 12 & kimcil & kimpet + cilik & Ukuran alat kelamin perempuan yang kecil \\
\hline 13 & igo & $\begin{array}{l}\text { Indonesian Girls } \\
\text { Only }\end{array}$ & Kumpuan foto-foto sensual perempuan Indonesia \\
\hline 14 & jilmek & jilat + memek & Aktivitas seksual yang ditujukan kepada perempuan \\
\hline 15 & panlok & panda + lokal & Sebutan untuk perempuan keturunan Tionghoa \\
\hline 16 & tobrut & toket + brutal & Ukuran payudara perempuan yang besar \\
\hline 17 & mekbem & memek + tembem & Ukuran alat kelamin perempuan yang besar \\
\hline 18 & meki & memek + kecil & Ukuran alat kelamin perempuan yang kecil \\
\hline 19 & tocil & toket + kecil & Ukuran payudara perempuan yang kecil \\
\hline 20 & sagapung & $\begin{array}{l}\text { sange }+ \text { ga }+ \\
\text { ketampung }\end{array}$ & hasrat berhubungan seksual yang berlebihan \\
\hline
\end{tabular}

Makna konteks dari akronim pornografis dibentuk dari beberapa faktor, antara lain foto, video, da persepsi yang membingkai wacana. Berikut beberapa contoh proses pemaknaan dari akronim pornografis. Meki merupakan akronim dari "memek kecil". Secara denotatif, meki bermakna ukuran alat kelamin perempuan yang masih kecil. Akan tetapi, di twitter, akronim meki digunakan untuk merujuk foto anak pelajar yang berpakaian seksi. Meki yang awalnya bermakna ukuran alat kelamin perempuan yang masih kecil mengalami perubahan makna karena persepsi masyarakat Indonesia melabeli bahwa jenis perempuan yang mempunyai vagina kecil adalah seorang pelajar sehingga meki digunakan untuk merujuk ke foto anak pelajar perempuan. Lalu, ngewe merupakan akronim dari" ngentot cewe". Secara denotatif, ngewe berarti berhubungan seksual dengan perempuan. Dalam konteks ini, pihak laki-laki sebagai subjek yang mengujarkan tuturan tersebut. Akan tetapi, dalam penggunaanya ngewe dapat digunakan oleh perempuan untuk mengajak laki-laki berhubungan seksual atau pada hubungan homoseksual. Hal itu membuat makna ngewe yang awalnya ditujukan dari laki-laki untuk mengajak perempuan berhubungan seksual tetapi mengalami bias gender dalam penggunaannya.

Adapun contoh lain, yakni akronim bispak. Bispak merupakan akronim dari "bisa pakai". Secara denotatif, bispak berarti bisa memakai sesuatu. Akan tetapi, dalam konteks porno, bispak mengalami perubahan makna menjadi perempuan yang dapat diajak berhubungan seksual. Hal tersebut dapat dipengaruhi oleh persepsi masyarakat. Koncil merupakan akronim dari "kontol cilik". Secara denotatif, koncil bermakna penis yang kecil. Akan tetapi, dalam konteks porno, koncil digunakan sebagai label dari bocah laki-laki pelajar yang mempunyai hasrat seksual kepada perempuan yang lebih dewasa. Selain itu, koncil digunakan sebagai hinaan seksual untuk laki-laki yang memiliki penis kecil. Lalu, akronim panlok juga mengalami perubahan makna dari unsur pembentuk akronimnya. Panlok merupakan akronim dari "panda lokal". Secara leksikal, "panda lokal" bermakna panda yang berasal dari Indonesia atau lokal. Akan tetapi, dalam konteks pornografi bermakna perempuan, sebagai objek seksual, yang beretnis Tionghoa. Hal tersebut terdapat asosiasi makna antara bentuk lingual akronim panlok dengan objek foto atau video. Bentuk asosiatif berupa leksem "panda" yang mengacu pada hewan yang berasal dari Tiongkok. Oleh karena itu, terbentuk makna perempuan sebagai objek seksual yang bertenis Tionghoa. 


\section{Dominasi Maskulin dalam Penggunaan Akronim Pornografis}

Dalam penggunaan akronim, stigma tabu dan kasar masih didapati di dalam akronim pornografis. Beberapa ungkapan yang dikategorikan sebagai persoalan yang tabu seperti seks, kematian, ekskresi, fungsi organ tubuh, binatang, dan masalah keagamaan (Wardhaugh 2006). Ekspresiekspresi yang berkaitan dengan persoalan di atas secara umum bisa dikategorikan sebagai ungkapan yang tabu dalam konteks penggunaan bahasa tentunya. Akronim pornografis berkaitan dengan penggunaan bahasa mengenai seks, fungsi tubuh, dan eskresi. Seks (sex), merupakan penyebutan yang mengarah pada hubungan intim seperti berkata seks, persetubuhan, dan sebagainya. Lalu, fungsi tubuh (bodily function), merupakan ekspresi dengan penyebutan organ tubuh manusia yang vital baik laki-laki dan perempuan seperti kemaluan atau ungkapan yang berkaitan dengan fungsi tubuh tertentu. Ekskresi (excretion), merupakan ungkapan yang berkaitan dengan proses pembuangan dari organ seksual dan fungsi organ tubuh yang tidak umum.

Bahasa yang digunakan oleh pria dan wanita memiliki perbedaan. Wanita memiliki kecenderungan menggunakan bahasa yang lebih sopan dibandingkan penggunaan bahasa pria (Lakoff 1975). Pria cenderung menggunakan bentuk vernakular atau bahasa sehari-hari dan bahasa lebih tidak baku dibandingkan bahasa yang digunakan wanita. Wanita tidak memiliki keleluasan ketika berbicara atau berujar mengenai hal yang tabu dan kasar. Hal tersebut disebabkan oleh konstruksi masyarakat patriarkal yang mengganggap pria adalah koordinat, dan wanita sebagai subordinat dari pria. Dari hal tersebut, terjadi bentuk kekuasaan dari pria kepada wanita. Menurut Foucault (dalam Johnson dan Meinhof 1997), kekuasaan adalah tindakan yang mempengaruhi tindakan lain. Efek dari tindakan diimplementasikan secara tidak langsung atau tidak nyata. Misalnya, kekuasaan terjadi karena tindakan yang memberikan efek dari tindakan lain dari kelompok orang yang dikuasai.

Menurut sejarah, kaum wanita telah dikucilkan dari produksi bentuk budaya (bahasa merupakan produksi budaya paling penting). Bahasa telah dibuat oleh pria dan telah menggunakannya untuk tujuan mereka sendiri (Spender 1980). Monopoli atas bahasa merupakan salah satu sarana para pria untuk memastikan keunggulan maskulin. Oleh sebab itu, pihak maskulin mengembangkan beberapa kosakata baru, sementara para wanita terus menggunakan ragam bahasa yang standar atau bahasa yang diwariskan (Spender 1980: 12). Flexner (dalam Spender 1980) menyimpulkan bahwa di dalam penggunaan bahasa slang atau bahasa gaul di Amerika Serikat, pria merupakan penanda, pencatat, dan pengembang atau inovator dari bahasa tersebut. Menurut Ardener (dalam Spender 1980) pria mengontrol register-register dalam wacana di masyarakat, sehingga makna dan bentuk register bahasa dalam wacana di masyarakat dikodekan dan dikendalikan oleh pria. Pria merasa nyaman dengan berbicara di masyarakat karena itu merupakan medium mereka dan diterima oleh nilai-nilai masyarakat. Hal tersebut menyebabkan akronim pornografis dikembangkan dan dikodekan oleh pria karena pria lebih leluasa berbicara mengenai hal porno atau seksual di masyarakat dibandingkan perempuan. Berikut ini adalah gambaran atau presentase pembahasan topik pornografi oleh laki-laki dan perempuan.

Dari 60 responden laki-laki, sebanyak $18,3 \%$ sering membahas topik pornografi di lingkungannya, $36,7 \%$ cukup sering membahas topik pornografi di lingkungannya, dan $45 \%$ sekali-kali atau jarang membahas topik pornografi di lingkungannya. Untuk perbandingan, lihat diagram presentase perempuan mmembahas topik ponrnografi sebagai berikut

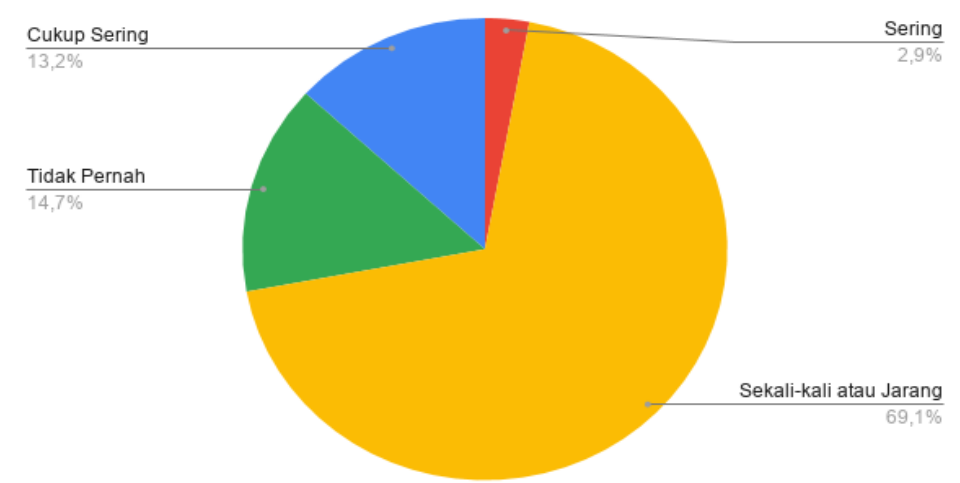

Diagram 1. Presentase Laki-Laki Membahas Topik Pornografi 
Dari 68 responden perempuan, sebanyak 2,9\% sering membahas topik pornografi di lingkungannya, $13,2 \%$ cukup sering membahas topik pornografi di lingkungannya, 69,1\% sekali-kali atau jarang membahas topik pornografi di lingkungannya, dan $14,7 \%$ tidak pernah membahas topik pornografi di lingkungannya.

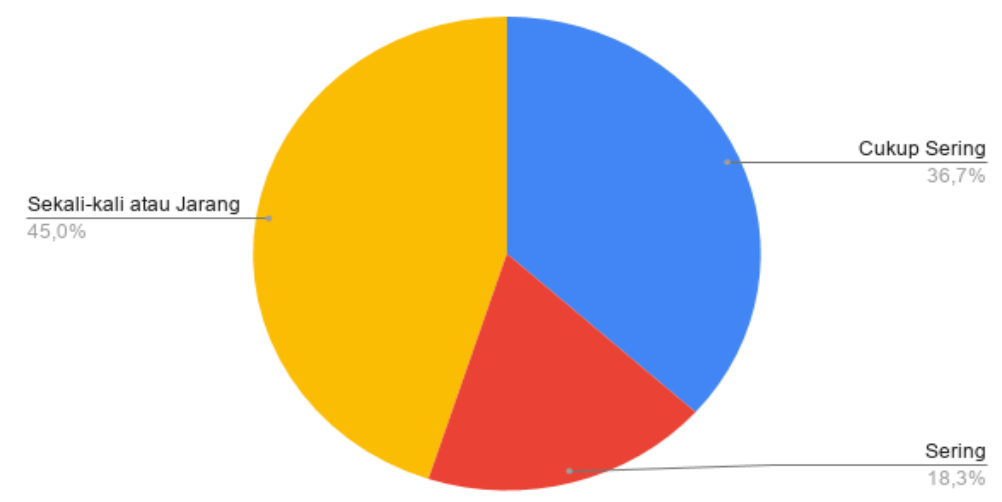

Diagram 2. Presentase Perempuan Membahas Topik Pornografi

Berdasarkan data survei, laki-laki lebih sering membahas topik pornografi dibandingkan perempuan. Hal tersebut memperkuat asumsi bahwa akronim pornografi, atau istilah pornografi, diciptakan dan dikembangkan oleh laki-laki. Perempuan turut memakai akronim pornografi yang sudah dibuat dan dikembangkan oleh laki-laki. Dominasi pria di dalam bahasa disebabkan oleh dominasi secara politik dan budaya oleh pria kepada wanita di dalam masyarakat (Sadiqi 2002). Hal-hal yang dibicarakan oleh laki-laki dan perempuan merefelksikan realitas sosial, laki-laki cenderung leluasa dalam berbicara sedangkan perempuan lebih tidak leluasa). Adapun bentuk dominasi maskulin dalam akronim pornografis antara lain; dominasi dalam hal membicarakan hal-hal tabu, seperti pornografi, dan pembentukan referen-gender dalam akronim pornografi.Menurut Referen-gender dalam pornografi dilihat melalui gender apa yang dijadikan referen dalam pembentukan makna akronim pornografis. Berikut diagram presentase referen-gender dalam akronim pornografis.

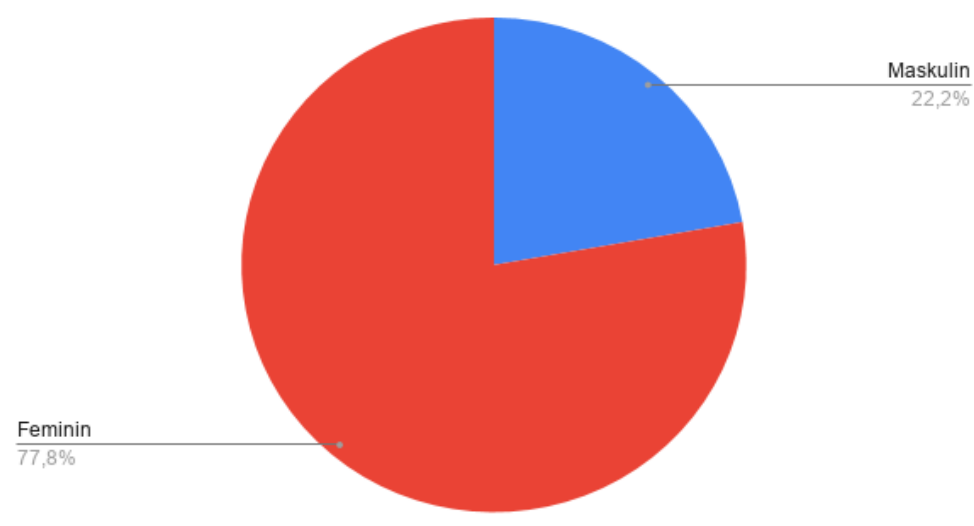

\section{Diagram 3. Presentase Referen-Gender dalam Akronim Pornografis}

Dari 19 akronim pornografis yang ditemukan, terdapat $77,8 \%$ referen-gender feminin dan $22,2 \%$ referen-gender maskulin. Pornografi merupakan hal yang dianggap tabu dan memiliki stigma buruk dalam masyarakat. Akan tetapi, mayoritas referen dari akronim pornografis ialah gender feminin. Hal tersebut menunjukkan kekerasan simbolik dari pihak maskulin terhadap feminin. Pihak maskulin menciptakan akronim pornografis yang mayoritas bereferen feminin untuk kepentingan maskulin. Struktur-struktur sosial dan struktur-struktur aktivitas produktif dan reproduktif itu hadir atas dasar pembagian seksual kerja produksi dan reproduksi biologis dan sosial yang memberikan bagian terbaik bagi laki-laki (Bourdieu 2010). Dominasi maskulin terhadap bahasa ini adalah media untuk 
melanjutkan kekerasan simbolik pada feminin. Berikut ini beberapa diagram presentase pengetahuan antara laki-laki dan perempuan mengenai akronim pornografis

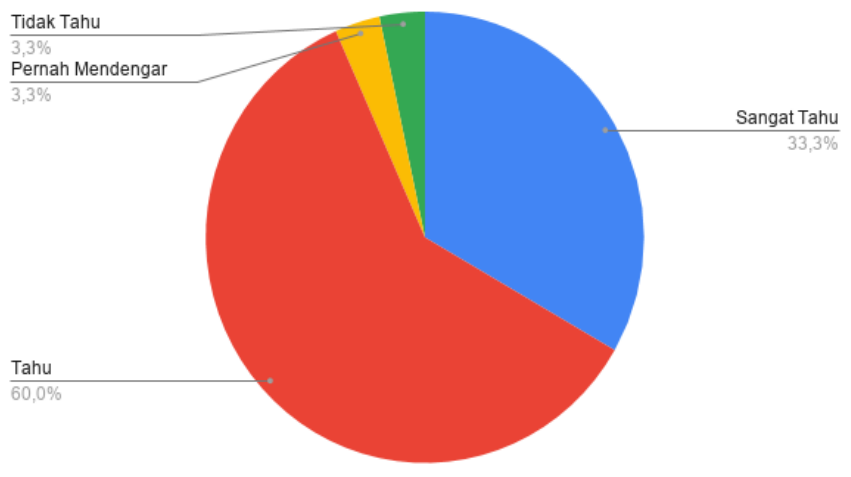

Diagram 4. Presentase Pengetahuan Akronim "colmek" bagi Laki-Laki

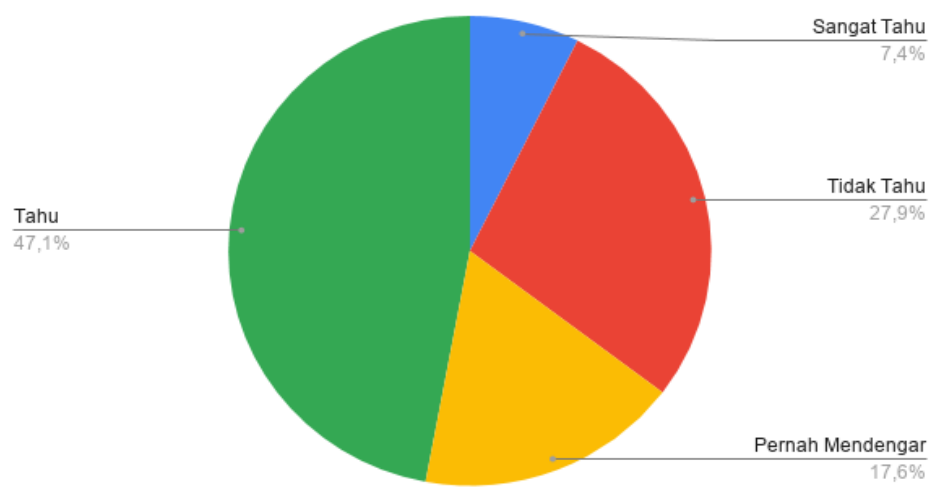

Diagram 5. Presentase Pengetahuan Akronim “colmek" bagi Perempuan

Berdasarkan data di atas, terdapat 33,3\% responden laki-laki sangat tahu dan 3,3\% responden lakilaki tidak tahu mengenai makna akronim pornografis colmek, sedangkan 7,4\% responden perempuan sangat tahu dan $27,9 \%$ responden perempuan tidak tahu mengenai makna akronim pornografis colmek. Sebanyak 60\% responden laki-laki dan $47,1 \%$ responden perempuan tahu mengenai makna akronim pornografis colmek. Padahal, referen dari akronim pornografis colmek mengacu pada kegiatan mastrubasi bagi perempuan. Akan tetapi, perempuan lebih banyak tidak mengetahui makna dari akronim pornografis colek dibandingkan dengan laki-laki. Hal tersebut menunjukkan bahwa terjadi eksploitasi, yang menjadikan perempuan sebagai objek seksual dalam wujud akronim. Contoh colmek memiliki asosiasi langsung yang merujuk kepada organ genital perempuan dalam pemaknaannya. Adapun contoh akronim yang secara leksikal tidak berasosiasi langsung dengan hal pornografi atau tabu, tetapi makna akronim diasosiasikan dengan konteks, yakni bispak (bisa pakai). Berikut adalah diagram presentase mengenai akronim pornografis bispak

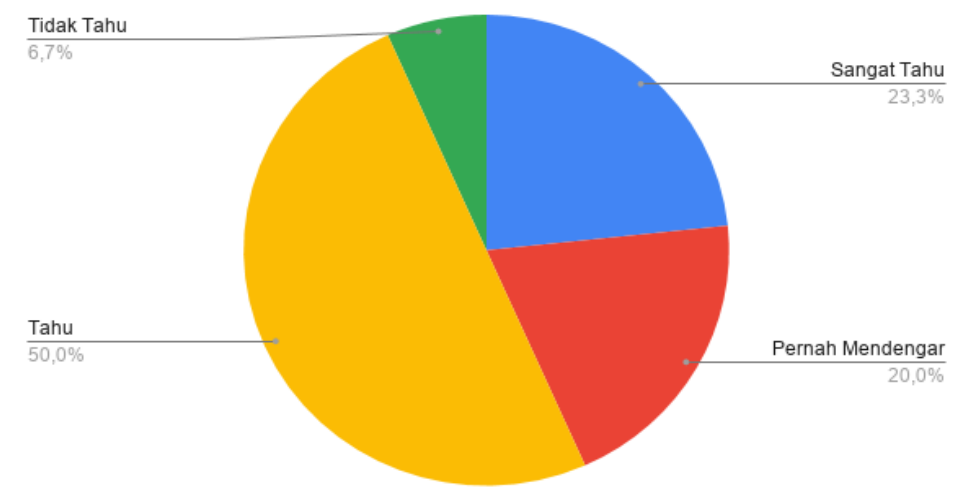

Diagram 5. Presentase Pengetahuan Akronim bispak bagi Laki-Laki 


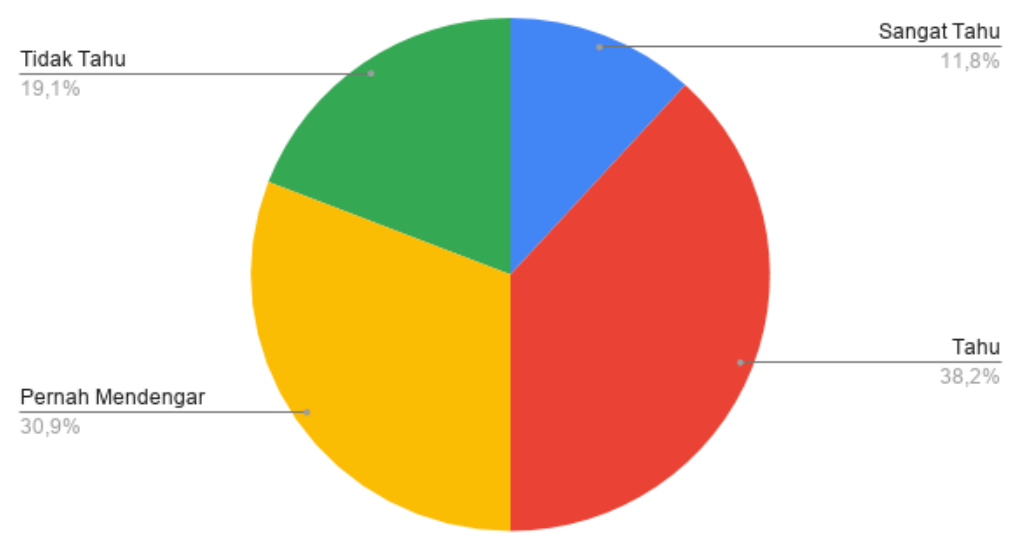

Diagram 6. Presentase Pengetahuan Pornografis bispak bagi Perempuan

Data tersebut menunjukkan bahwa terdapat $23 \%$ responden laki-laki dan $11,8 \%$ responden perempuan sangat tahu mengenai makna akronim pornografis bispak. Lalu, terdapat $50 \%$ responden laki-laki dan 38,2 \% responden perempuan tahu mengenai makna akronim pornografis bispak. 6,7\% responden laki-laki dan $19,1 \%$ responden perempuan tidak tahu mengenai makna akronim pornografis bispak. Bispak memiliki makna perempuan yang dapat diajak berhubungan seksual oleh siapa pun. Objektivikasi perempuan dalam akronim bispak menandakan dominasi maskulinitas. Dalam akronim bispak, perempuan menjadi objek dari suatu hal yang tabu dan tidak senonoh. Strategi penggunaan akronim dengan menggunakan dua kata atau leksem yang tidak ada unsur pornografis menjadi cara maskulin untuk merahasiakan maksud tuturan dalam akronim bispak. Dominasi diperkuat ketika perempuan yang mengetahui makna akronim bispak turut menggunakan akronim tersebut, ketika perempuan melabeli diri sebagai seorang yang bisa diajak berhubungan seksual.

\section{KESIMPULAN}

Fenomena perkembangan pornografi di dalam media sosial twitter memunculkan terciptanya berbagai akronim pornografis. Bentuk akronim pornografis digunakan sebagai kode untuk merahasiakan maksud-maksud yang berkaitan dengan hal tabu atau porno. Adapun, akronim pornografis memiliki beberapa varian secara bentuk lingual, antara lain berupa akronim tiga kata, akronim suku kata awal dengan suku kata awal, akronim suku kata awal dengan suku kata akhir, dan akronim dengan kata metatesis, campur kode ke dalam (bahasa Indonesia dengan bahasa daerah), campur kode ke luar (bahasa Indonesia dengan bahasa Inggris), bahasa prokem, dan bahasa Inggris.

Lalu, makna akronim pornografis mengalami perluasan dari makna-makna leksikal yang menjadi unsur pembentuk akronim. Hal tersebut disebabkan oleh faktor-faktor di luar bahasa yang menjadi konteks pornografi, seperti foto dan video. Dominasi maskulinitas dalam akronim pornografi dapat dilihat dari gender maskulin menciptakan dan mengembangkan pembentukan akronim pornografis. Hal tersebut dapat dilihat berdasarkan survei, frekuensi laki-laki membicarakan topik pornografi lebih besar dibandingkan perempuan. Dalam penggunaan akronim pornografis, terdapat kekerasan simbolik terhadap gender feminin karena berdasarkan referen akronim pornografi, feminin memiliki presentase lebih besar dibandingkan dengan maskulin, sehingga feminin dijadikan sebagai objektivikasi dalam pembentukan akronim pornografis.

\section{DAFTAR PUSTAKA}

Bourdieu, Pierre. 2010. Dominasi Maskulin. Diterjemahkan oleh Stephanus Aswar Herwinarko. Yogyakarta: Jala Sutra.

Ensiklopedi nasional Indonesia. 1990. Jakarta: PT Cipta Adi Pustaka.

Fine, Marlene G., dan Fern L. Johnson. 1984. "Female and Male Motives for Using Obscenity." Journal of Language and Social Psychology 3 (1). SAGE Publications Inc: 59-74. doi:10.1177/0261927X8431004. 
Aditya Wicaksono \& Sailal Arimi

Holmes, Janet. 2012. An Introduction to Sociolinguistics. Learning about Language. New York: Routledge.

Johnson, Sally, dan Ulrike Hanna Meinhof. 1997. Language and Masculinity. Oxford: Blackwell.

Koentjaraningrat. 2009. Pengantar ilmu Antropologi. Jakarta: Rineka Cipta.

Kridalaksana, Harimurti. 2001. Kamus linguistik. Jakarta: Gramedia Pustaka Utama.

Lakoff, Robin T. 1975. Language and Woman's Place. Harper Colophon Books. New York; London: Harper and Row.

Mahsun. 2012. Metode penelitian bahasa: tahap strategi, metode, dan tekniknya. Jakarta: Rajawali Press.

Mesthrie, Rajend. 2009. Introducing Sociolinguistics. Edinburgh: Edinburgh Univ. Press.

Spender, Dale. 1980. Man Made Language. 2nd ed. London: Routledge \& Kegan Paul.

Sugihastuti, dan Siti Hariti Sastriyani. 2007. Glosarium seks dan gender. Sleman, Yogyakarta: ÇarasvatiBooks. http://books.google.com/books?id=opgkAAAAMAAJ.

Suwito. 1985. Sosiolinguistik: Pengantar awal. Surakarta: Henary Offset Solo. http://opac.lib.ugm.ac.id/index.php?mod=book_detail\&sub=BookDetail\&act=view\&typ=htm lext\&buku_id=698992\&obyek_id=1.

Talbot, Mary M. 2003. Language and Gender. Cambridge: Polity Press.

Tarigan, Henry Guntur. 1988. Pengajaran morfologi. Bandung: Angkasa.

Wardhaugh, Ronald. 2006. An Introduction to Sociolinguistics. Oxford: Blackwell. 